\title{
Investigation on silver complexes of novel 1,2,3-triazole linked crown ethers by NMR analysis
}

\author{
PIOTR SELIGER $^{\mathrm{a}, *}$, NATALIA GUTOWSKA ${ }^{\mathrm{a}}$, MONIKA STEFANIAK $^{\mathrm{b}}$ and \\ JAROSŁAW ROMAŃSKI ${ }^{\mathrm{b}}$ \\ ${ }^{a}$ Department of Inorganic and Analytical Chemistry, Faculty of Chemistry, University of Łódź, Tamka 12, \\ PL-91-403 Łódź, Poland \\ ${ }^{\mathrm{b}}$ Department of Organic and Applied Chemistry, Faculty of Chemistry, University of Łódź, Tamka 12, \\ PL-91-403 Łódź, Poland \\ e-mail: pitsel@chemia.uni.lodz.pl
}

MS received 27 February 2015; revised 7 May 2015; accepted 20 July 2015

\begin{abstract}
The novel derivatives of 1,2,3-triazole linked crown ethers were investigated towards silver(I) ion coordination. The NMR measurements in deuterated methanol in different ratios of ligand and silver cation were studied. The experiments were performed in order to examine the way of binding Ag(I) ion by the selected ligands. The results are presented for complexes with the Ag:L stoichiometry $0.5: 1,1: 1$ and $2: 1$, respectively. Depending on the type of crown ether moiety incorporated into the macrocyclic skeleton, interesting differences in the mode of stepwise coordination of the ion were noticed.
\end{abstract}

Keywords. Macrocyclic system; silver complex; 1,2,3-triazole; crown ethers; sulfur compounds

\section{Introduction}

The synthetic strategy towards macrocyclic systems and the study of their properties have drawn the attention of chemists for many years. It is well known that in the case of preparation, in principle, inter- or intramolecular processes are achieved by usage of high dilution or template methodology. Recently, the click azide-alkyne cycloaddition catalyzed by copper(I) $(\mathrm{CuAAC})^{1,2}$ was implemented as a powerful tool for synthesis of various molecules ${ }^{3-5}$ as well as macrocyclic compounds. ${ }^{6-9}$ The main goal of research in the field of macrocyclic systems is to investigate their properties and potential application in molecular recognition, complexation, catalysis, analysis and construction the modified electrodes, etc. ${ }^{10-16}$

All of the investigated ligands possess several structural units which can potentially take part in binding of metal cations: oxygen atom donors in polyether crown skeleton, sulfur atoms as soft donors as well as the endocyclic nitrogen atoms of 1,2,3-triazole rings incorporated into the macrocyclic structure. Due to the presence of such different binding sites, these ligands should interact with cations to form stable complexes with alkali metals and alkaline earth metals as well as transition metals. ${ }^{17-19}$ In this paper the preliminary

*For correspondence results of selected macrocycles and the scope of their complexation ability to silver cation are described.

\section{Experimental}

\subsection{Materials}

The ligands were synthesized according to the previously described procedure. ${ }^{20}$ Deuterated methanol $\left(\mathrm{CD}_{3} \mathrm{OD}\right)$ was purchased from Sigma-Aldrich. Silver(I) nitrate was purchased from Sigma Aldrich and used without further purification.

\subsection{Methods}

NMR spectra for compounds L1, L2 (figure 1) and their silver (I) complexes were recorded in $\mathrm{CD}_{3} \mathrm{OD}$ on a Bruker Avance III 600 spectrometer $\left({ }^{1} \mathrm{H}-\mathrm{NMR}\right.$ at $600 \mathrm{MHz}$ and ${ }^{13} \mathrm{C}$ NMR at $\left.151 \mathrm{MHz}\right)-{ }^{1} \mathrm{H}$ NMR spectra of the complexes are shown in electronic Supporting Information (SI) (figures S1-S8). Additionally, HMBC and HMQC spectra of complexes were taken in order to correlate the structural assignments of ligands and are depicted in SI (figures S9-S12). ESI-MS spectra were recorded using a Varian 500-MS LC ion-trap mass spectrometer (Palo Alto, CA, USA). All samples were introduced into the ESI-MS source in continuous infusion by means of the instrument syringe pump at a rate of 


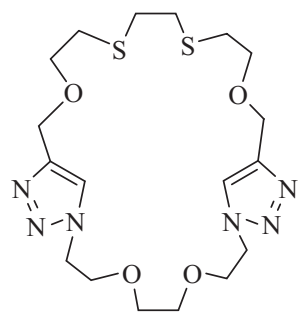

L1

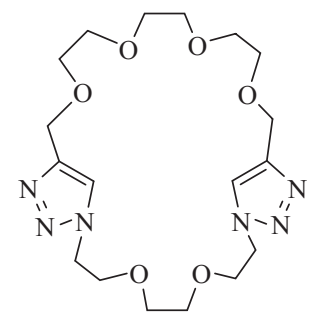

L2
Figure 1. The investigated macrocyclic ligands.

$10 \mu \mathrm{L} \mathrm{m^{-1 }}$. The ESI-source was operated at $5.00 \mathrm{kV}$ and the capillary heater was set to $300^{\circ} \mathrm{C}$. The cone voltage was regulated within the range $50-120 \mathrm{~V}$. Scanning was performed from $\mathrm{m} / \mathrm{z}=300$ to 1200 .

\subsection{Theoretical calculations}

All the MD calculations were performed using the TURBOMOLE package. ${ }^{21}$ DFT molecular dynamics calculations were carried out with BLYP functional ${ }^{22}$ along with triple- $\xi$ valence polarized basis set (TZVP) within the resolution-of-the-identity (RI) approximation. ${ }^{23}$

\section{Results and Discussion}

Selected diazides as well as bis(propargyl) ethers were used as crucial building blocks for the construction of macrocyclic crown ethers and thioethers with built-in 1,2,3-triazole rings ${ }^{20,24}$ (scheme 1).

In the final macrocyclisation step, diazides and terminal bis(alkynes) were reacted in the presence of catalyticamount of copper(I) iodide under the 'click' 1,3-dipolar cycloaddition methodology. ${ }^{20,24}$ To obtain the desired products in best yields, high dilution conditions were applied. To the best of our knowledge, the syntheses and properties of such macrocyclic systems, including their sulfur analogues, are little known so far. ${ }^{25}$

For the present study, two crown derivatives were selected to examine the modes of coordination of silver ions depending on the changes inside the macrocyclic ring. In one of the selected ligand, two sulfur atoms were incorporated into the polyether moiety instead of oxygen. The complexation properties of this kind of crown compounds have not been studied so far and the presented results can be a good starting point for further detailed research. The investigated ligands L1 and L2 are shown in figure 1.

Complexing properties of the ligand L1 were screened towards binding with silver(I) cations by NMR measurements. To check the ability and mode of binding of silver ions, a series of ${ }^{1} \mathrm{H}-\mathrm{NMR}$ spectra were taken in $\mathrm{CD}_{3} \mathrm{OD}$ for the pure ligand $\mathbf{L} \mathbf{1}$ and mixtures obtained after addition of appropriate amounts of silver(I) nitrate to achieve the stoichiometry $\mathrm{Ag}^{+}: \mathrm{L}_{\text {equal }}$ $0.5: 1,1: 1$, and 2:1. The obtained results are presented in table 1 .

In the case of sulfur derivative L1, the coordination of silver ion seems to occur at the beginning through the step of coordination binding by sulfur atoms from the macrocyclic chain to form probably sandwich-like complex. Such a conclusion has been drawn from the main shifts of the signals which are observed in macrocyclic moiety near the region when sulfur atoms are incorporated in the chain (figure 2) after addition of the silver ions corresponding to $0.5: 1\left(\mathrm{Ag}^{+}: \mathbf{L 1}\right)$ stoichiometry.

These proton shifts are probably associated with the incorporation of silver cation inside the macrocyclic cavity in the first stage of formation sandwich-like complex and suggests that the metal ion locates out of the plane of macrocyclic ring allowing coordination by the second molecule of the ligand. The very small shift for 1,2,3-triazole ring protons support the above mentioned hypothesis as can be seen from the signals within the region (figure 3, spectra (a) and (b)). Similar sandwich complex for macrocyclic $\mathrm{Ag}(\mathrm{I})$ systems were reported in the literature on the basis of potentiometric as well as mass spectrometric measurements. ${ }^{19,26,27}$ Schematic presentation of the sandwich like complex is presented on figure S13 in SI. Although in the ESI-MS spectra there is no signal for the original sandwich complexes, in the spectrum within the region above $\mathrm{m} / \mathrm{z}=600$ we can notice two signal pairs at m/z 691-693 and 891-893

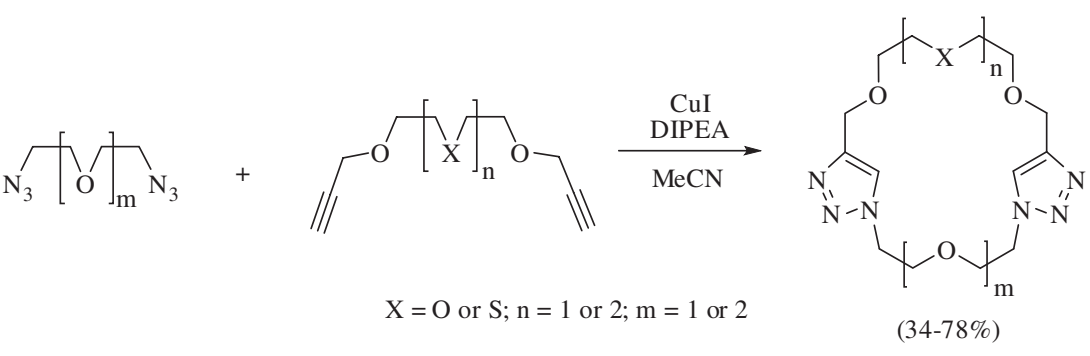

Scheme 1. Synthesis of 1,2,3-triazole-linked macrocycles. 
Table 1. The ${ }^{1} \mathrm{H}-\mathrm{NMR}$ and ${ }^{13} \mathrm{C}-\mathrm{NMR}$ results of complexation of $\mathbf{L} \mathbf{1}$ by silver ion in $\mathrm{CD}_{3} \mathrm{OD}$.

\begin{tabular}{|c|c|c|c|}
\hline & ${ }^{1} \mathrm{H}$ NMR & ${ }^{13} \mathrm{C} \mathrm{NMR}$ & \\
\hline L1 & $\begin{array}{c}- \\
7.99, \mathrm{~s}, 2 \mathrm{H} \\
4.61, \mathrm{~s}, 4 \mathrm{H} \\
4.54, \mathrm{t}, 4 \mathrm{H}, \mathrm{J}=5.01 \mathrm{~Hz} \\
3.82, \mathrm{t}, 4 \mathrm{H}, \mathrm{J}=5.08 \mathrm{~Hz} \\
3.69, \mathrm{t}, 4 \mathrm{H}, \mathrm{J}=6.23 \mathrm{~Hz} \\
3.58, \mathrm{~s}, 4 \mathrm{H} \\
2.69, \mathrm{~s}, 4 \mathrm{H} \\
2.65, \mathrm{t}, 4 \mathrm{H}, \mathrm{J}=6.30 \mathrm{~Hz}\end{array}$ & $\begin{array}{l}145.9 \\
125.8 \\
64.8 \\
51.4 \\
70.2 \\
72.2 \\
71.3 \\
33.7 \\
32.2\end{array}$ & $\begin{array}{l}-\mathrm{NC} \\
-\mathrm{CHN} \\
-\mathrm{OC} \\
-\mathrm{CH}_{2} \mathrm{~N} \\
-\mathrm{CH}_{2} \mathrm{O} \\
-\mathrm{OCH}_{2} \\
-\mathrm{OC} \\
-\mathrm{SCH}_{2} \mathrm{CS} \\
-\mathrm{CH}_{2} \mathrm{~S}\end{array}$ \\
\hline $\mathrm{Ag}^{+}: \mathbf{L} \mathbf{1}(0.5: 1)$ & $\begin{array}{c}- \\
7.98, \mathrm{~s}, 2 \mathrm{H} \\
4.66, \mathrm{~s}, 4 \mathrm{H} \\
4.54, \mathrm{t}, 4 \mathrm{H}, \mathrm{J}=4.91 \mathrm{~Hz} \\
3.83, \mathrm{t}, 4 \mathrm{H}, \mathrm{J}=5.02 \mathrm{~Hz} \\
3.75, \mathrm{t}, 4 \mathrm{H}, \mathrm{J}=5.55 \mathrm{~Hz} \\
3.57, \mathrm{~s}, 4 \mathrm{H} \\
2.94, \mathrm{~s}, 4 \mathrm{H} \\
2.88, \mathrm{t}, 4 \mathrm{H}, \mathrm{J}=5.48 \mathrm{~Hz}\end{array}$ & $\begin{array}{l}145.7 \\
125.3 \\
64.4 \\
51.7 \\
70.2 \\
70.2 \\
71.3 \\
33.6 \\
33.6\end{array}$ & $\begin{array}{l}-\mathrm{NC} \\
-\mathrm{CHN} \\
-\mathrm{OC} \\
-\mathrm{CH}_{2} \mathrm{~N} \\
-\mathrm{CH}_{2} \mathrm{O} \\
-\mathrm{OCH}_{2} \\
-\mathrm{OC} \\
-\mathrm{SCH}_{2} \mathrm{CS} \\
-\mathrm{CH}_{2} \mathrm{~S}\end{array}$ \\
\hline $\mathrm{Ag}^{+}: \mathbf{L} \mathbf{1}(1: 1)$ & $\begin{array}{c}- \\
8.00, \mathrm{~s}, 2 \mathrm{H} \\
4.71, \mathrm{~s}, 4 \mathrm{H} \\
4.57, \mathrm{t}, 4 \mathrm{H}, \mathrm{J}=4.78 \mathrm{~Hz} \\
3.84, \mathrm{t}, 4 \mathrm{H}, \mathrm{J}=4.97 \mathrm{~Hz} \\
3.76, \mathrm{t}, 4 \mathrm{H}, \mathrm{J}=4.70 \mathrm{~Hz} \\
3.58, \mathrm{~s}, 4 \mathrm{H} \\
3.06, \mathrm{~s}, 4 \mathrm{H} \\
3.00, \mathrm{t}, 4 \mathrm{H}, \mathrm{J}=5.18 \mathrm{~Hz}\end{array}$ & $\begin{array}{l}145.8 \\
125.1 \\
64.1 \\
52.0 \\
70.2 \\
69.0 \\
71.4 \\
34.1 \\
33.7\end{array}$ & $\begin{array}{l}-\mathrm{NC} \\
-\mathrm{CHN} \\
-\mathrm{OC} \\
-\mathrm{CH}_{2} \mathrm{~N} \\
-\mathrm{CH}_{2} \mathrm{O} \\
-\mathrm{OCH}_{2} \\
-\mathrm{OC} \\
-\mathrm{SCH}_{2} \mathrm{CS} \\
-\mathrm{CH}_{2} \mathrm{~S}\end{array}$ \\
\hline $\mathrm{Ag}^{+}: \mathbf{L} \mathbf{1}(2: 1)$ & $\begin{array}{c}- \\
8.10, \mathrm{~s}, 2 \mathrm{H} \\
4.73, \mathrm{~s}, 4 \mathrm{H} \\
4.65, \mathrm{t}, 4 \mathrm{H}, \mathrm{J}=4.70 \mathrm{~Hz} \\
3.86, \mathrm{t}, 4 \mathrm{H}, \mathrm{J}=4.86 \mathrm{~Hz} \\
3.70, \mathrm{t}, 4 \mathrm{H}, \mathrm{J}=5.08 \mathrm{~Hz} \\
3.60, \mathrm{~s}, 4 \mathrm{H} \\
3.08, \mathrm{~s}, 4 \mathrm{H} \\
3.00, \mathrm{t}, 4 \mathrm{H}, \mathrm{J}=4.95 \mathrm{~Hz}\end{array}$ & $\begin{array}{l}146.0 \\
125.8 \\
63.8 \\
52.4 \\
70.2 \\
68.8 \\
71.4 \\
34.3 \\
34.3\end{array}$ & $\begin{array}{l}-\mathrm{NC} \\
-\mathrm{CHN} \\
-\mathrm{OC} \\
-\mathrm{CH}_{2} \mathrm{~N} \\
-\mathrm{CH}_{2} \mathrm{O} \\
-\mathrm{OCH}_{2} \\
-\mathrm{OC}^{-} \\
-\mathrm{SCH}_{2} \mathrm{CS} \\
-\mathrm{CH}_{2} \mathrm{~S}\end{array}$ \\
\hline
\end{tabular}

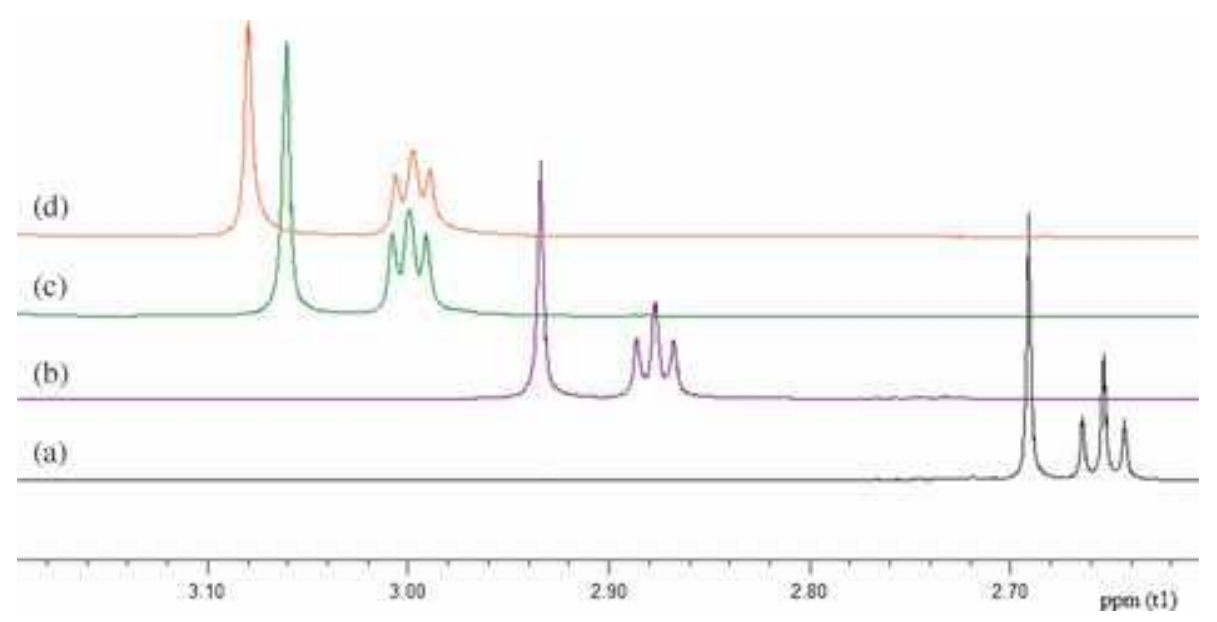

Figure 2. The ${ }^{1} \mathrm{H}-\mathrm{NMR}$ spectra of the $-\mathrm{CH}_{2}-\mathrm{S}-\mathrm{CH}_{2}$ - region in $\mathrm{CD}_{3} \mathrm{OD}$ for (a) uncomplexed ligand $\mathbf{L 1}$, and after adding silver ion with the $\mathrm{Ag}^{+}: \mathbf{L 1}$ molar ratio; (b) $0.5: 1$; (c) $1: 1$; and (d) $2: 1$. 


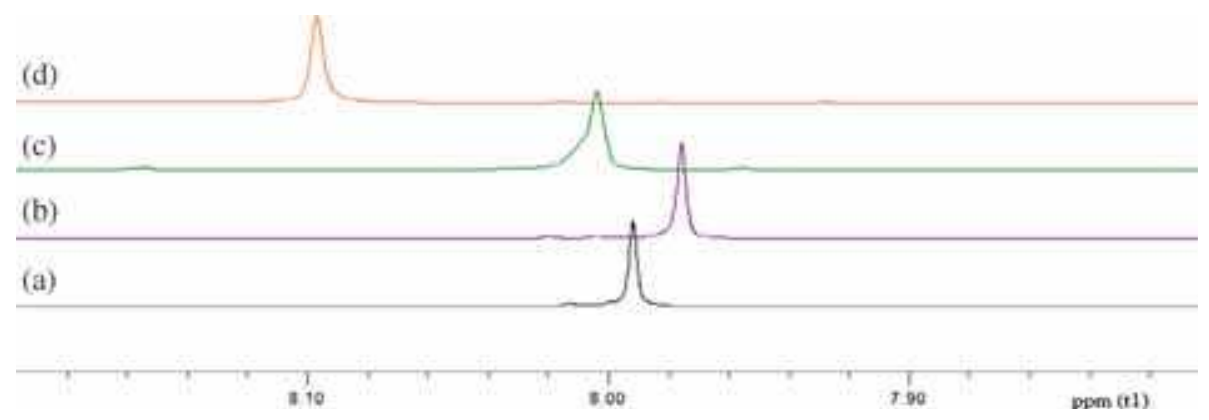

Figure 3. The ${ }^{1} \mathrm{H}-\mathrm{NMR}$ spectra of the 1,2,3-triazole ring proton in $\mathrm{CD}_{3} \mathrm{OD}$ for uncomplexed ligand $\mathbf{L 1}$ (a) and after adding silver ion for the $\mathrm{Ag}^{+}: \mathbf{L} \mathbf{1}$ molar ratio; (b) $0.5: 1$; (c) $1: 1$; and (d) $2: 1$.

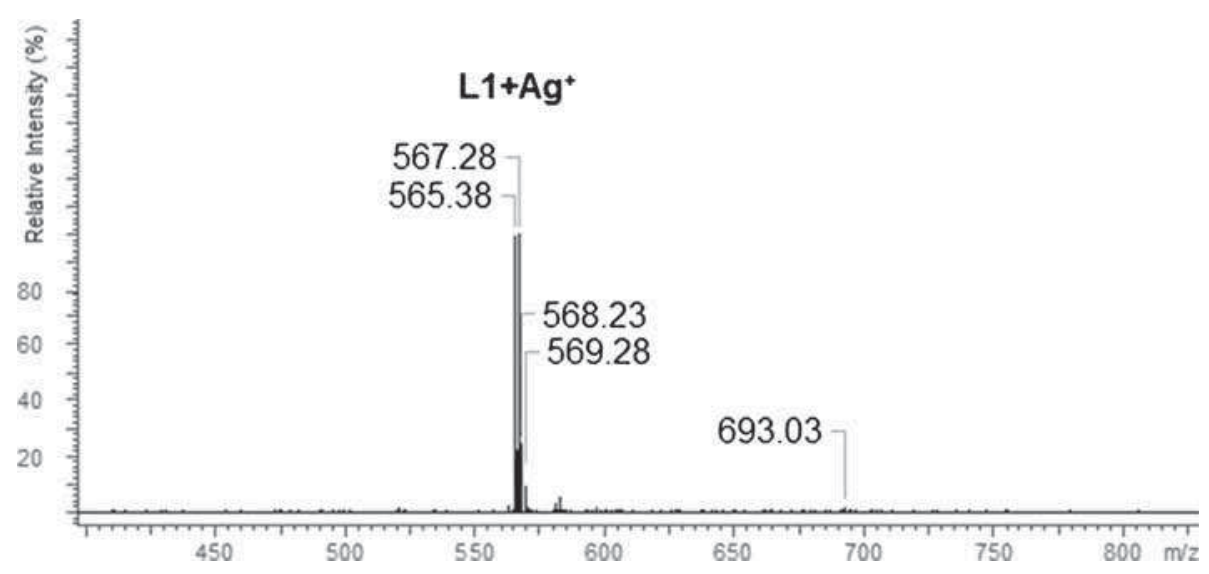

Figure 4. The ESI-MS spectrum of the complexes of $\mathbf{L} \mathbf{1}$ ligand with $\mathrm{Ag}^{+}$ions.

which can be attributed to a structure in which one of the macrocyclic rings has been fragmented during the ionization process. The comparison of isotope patterns of the signals show the presence of the silver ion in the structure. This fact can be used as indirect proof of the existence of the sandwich-like complex.

Further shift of $-\mathrm{CH}_{2} \mathrm{~S}$ - protons after addition of the next portion of silver ions (figure 3, spectrum (c)) suggests that after achieving 1:1 stoichiometry, the silver ions are nested inside the macrocyclic cavity but still have no interaction with the nitrogen atoms from 1,2,3-triazole subunits (figure 3 (a),(b) and (c)). The ESI-MS spectrum of the investigated system shows signal at $\mathrm{m} / \mathrm{z} 565.38$ with the characteristic isotopic pattern (figure 4). The interesting fact in the case of silver (I) complex with this ligand is that during the MS experiment no typical additional complexes with $\mathrm{Na}^{+}$or $\mathrm{K}^{+}$ions were observed and there was no signal of parent ligand at $\mathrm{m} / \mathrm{z} 459.60$. Such a behavior is typical for deeply nested metal cation inside the macrocyclic cavity forming very stable complexes.

Finally, the last portion of the silver ions was added which corresponds to the stoichiometry of 2:1 of
$\mathrm{Ag}^{+}: \mathbf{L 1}$. The spectrum (d) showed the downfield shift by $0.1 \mathrm{ppm}$ of the protons for 1,2,3-triazole ring (from 8.00 to $8.10 \mathrm{ppm}$ ) and the proton shift within the region assigned for the $\mathrm{CH}_{2}-\mathrm{N}$ moiety (from 4.57 to $4.65 \mathrm{ppm}$ ) was also observed. This kind of behavior indicates that the way of binding of the second silver ion is supported by the nitrogen atoms of 1,2,3-triazole rings in the macrocyclic structure. Due to the good stabilization of the 1:1 complex, the ESI-MS measurements showed only a very weak signal at $\mathrm{m} / \mathrm{z} 337.37(\mathrm{RT}<<1 \%)$. During the ionization process, the second silver ion is easily removed from the structure forming the most stable $1: 1$ complex.

Subsequently, the complexation of silver cation by ligand L2 was monitored by NMR. The results collected in table 2 indicate that the way of complexation is significantly different in comparison with that observed for the sulfur derivative $\mathbf{L 1}$.

In the first step the coordination seems to occur through the nitrogen atoms of the 1,2,3-triazole rings what can be connected with the significant downfield shifts of protons from the $\mathrm{CHN}$ region (figure 5, spectrum (b)). 
Table 2. The ${ }^{1} \mathrm{H}-\mathrm{NMR}$ and ${ }^{13} \mathrm{C}-\mathrm{NMR}$ results of complexation of $\mathbf{L} \mathbf{2}$ by silver ion in $\mathrm{CD}_{3} \mathrm{OD}$.

\begin{tabular}{|c|c|c|}
\hline & ${ }^{1} \mathrm{H}$ NMR & ${ }^{13} \mathrm{C}$ NMR \\
\hline $\mathbf{L} 2$ & $\begin{array}{c}- \\
7.98(\mathrm{~s}, 2 \mathrm{H},-\mathrm{CHN}) \\
4.63\left(\mathrm{~s}, 4 \mathrm{H},-\mathrm{OCH}_{2} \mathrm{C}\right) \\
4.53\left(\mathrm{t}, \mathrm{J}=5.01 \mathrm{~Hz}, 4 \mathrm{H},-\mathrm{CH}_{2} \mathrm{~N}\right) \\
3.83\left(\mathrm{t}, \mathrm{J}=5.08 \mathrm{~Hz}, 4 \mathrm{H},-\mathrm{CH}_{2} \mathrm{O}\right) \\
3.68\left(\mathrm{t}, \mathrm{J}=6.23 \mathrm{~Hz}, 4 \mathrm{H},-\mathrm{CH}_{2} \mathrm{O}\right) \\
3.67\left(\mathrm{~s}, 4 \mathrm{H},-\mathrm{O}\left(\mathrm{CH}_{2}\right)_{2} \mathrm{O}\right) \\
3.59\left(\mathrm{~s}, 4 \mathrm{H},-\mathrm{OCH}_{2}\right) \\
3.57\left(\mathrm{~s}, 4 \mathrm{H},-\mathrm{O}\left(\mathrm{CH}_{2}\right)_{2} \mathrm{O}\right)\end{array}$ & $\begin{array}{l}146.2 \\
125.8 \\
65.1 \\
51.8 \\
70.2 \\
70.8 \\
71.6 \\
71.2 \\
71.2\end{array}$ \\
\hline $\mathrm{Ag}^{+}: \mathbf{L 2}(0.5: 1)$ & $\begin{array}{c}8.13(\mathrm{~s}, 2 \mathrm{H},-\mathrm{CHN}) \\
4.77\left(\mathrm{~s}, 4 \mathrm{H},-\mathrm{OCH}_{2} \mathrm{C}\right) \\
4.62\left(\mathrm{t}, \mathrm{J}=4.93 \mathrm{~Hz}, 4 \mathrm{H},-\mathrm{CH}_{2} \mathrm{~N}\right) \\
3.83\left(\mathrm{t}, \mathrm{J}=4.83 \mathrm{~Hz}, 4 \mathrm{H},-\mathrm{CH}_{2} \mathrm{O}\right) \\
3.68\left(\mathrm{t}, \mathrm{J}=5.02 \mathrm{~Hz}, 4 \mathrm{H},-\mathrm{CH}_{2} \mathrm{O}\right) \\
3.67\left(\mathrm{~s}, 4 \mathrm{H},-\mathrm{O}\left(\mathrm{CH}_{2}\right)_{2} \mathrm{O}\right) \\
3.66\left(\mathrm{~s}, 4 \mathrm{H},-\mathrm{OCH}_{2}\right) \\
3.59\left(\mathrm{~s}, 4 \mathrm{H},-\mathrm{O}\left(\mathrm{CH}_{2}\right)_{2} \mathrm{O}\right)\end{array}$ & $\begin{array}{l}146.6 \\
125.8 \\
65.0 \\
51.8 \\
70.1 \\
70.8 \\
71.6 \\
71.2 \\
71.2\end{array}$ \\
\hline $\mathrm{Ag}^{+}: \mathbf{L} 2(1: 1)$ & $\begin{array}{c}- \\
8.11(\mathrm{~s}, 2 \mathrm{H},-\mathrm{CHN}) \\
4.76\left(\mathrm{~s}, 4 \mathrm{H},-\mathrm{OCH}_{2} \mathrm{C}\right) \\
4.59\left(\mathrm{t}, \mathrm{J}=4.88 \mathrm{~Hz}, 4 \mathrm{H},-\mathrm{CH}_{2} \mathrm{~N}\right) \\
3.83\left(\mathrm{t}, \mathrm{J}=4.79 \mathrm{~Hz}, 4 \mathrm{H},-\mathrm{CH}_{2} \mathrm{O}\right) \\
3.68\left(\mathrm{t}, \mathrm{J}=5.08 \mathrm{~Hz}, 4 \mathrm{H},-\mathrm{CH}_{2} \mathrm{O}\right) \\
3.67\left(\mathrm{~s}, 4 \mathrm{H},-\mathrm{O}\left(\mathrm{CH}_{2}\right)_{2} \mathrm{O}\right) \\
3.64\left(\mathrm{~s}, 4 \mathrm{H},-\mathrm{OCH}_{2}\right) \\
3.59\left(\mathrm{~s}, 4 \mathrm{H},-\mathrm{O}\left(\mathrm{CH}_{2}\right)_{2} \mathrm{O}\right)\end{array}$ & $\begin{array}{l}146.6 \\
125.7 \\
64.6 \\
51.8 \\
70.0 \\
70.8 \\
71.6 \\
71.2 \\
71.2\end{array}$ \\
\hline $\mathrm{Ag}^{+}: \mathbf{L 2}(2: 1)$ & $\begin{array}{c}- \\
8.15(\mathrm{~s}, 2 \mathrm{H},-\mathrm{CHN}) \\
4.77\left(\mathrm{~s}, 4 \mathrm{H},-\mathrm{OCH}_{2} \mathrm{C}\right) \\
4.64\left(\mathrm{t}, \mathrm{J}=4.72 \mathrm{~Hz}, 4 \mathrm{H},-\mathrm{CH}_{2} \mathrm{~N}\right) \\
3.84\left(\mathrm{t}, \mathrm{J}=4.74 \mathrm{~Hz}, 4 \mathrm{H},-\mathrm{CH}_{2} \mathrm{O}\right) \\
3.68\left(\mathrm{t}, \mathrm{J}=4.99 \mathrm{~Hz}, 4 \mathrm{H},-\mathrm{CH}_{2} \mathrm{O}\right) \\
3.67\left(\mathrm{~s}, 4 \mathrm{H},-\mathrm{O}\left(\mathrm{CH}_{2}\right)_{2} \mathrm{O}\right) \\
3.66\left(\mathrm{~s}, 4 \mathrm{H},-\mathrm{OCH}_{2}\right) \\
3.60\left(\mathrm{~s}, 4 \mathrm{H},-\mathrm{O}\left(\mathrm{CH}_{2}\right)_{2} \mathrm{O}\right)\end{array}$ & $\begin{array}{c}146.7 \\
125.9 \\
64.6 \\
51.8 \\
70.2 \\
70.8 \\
71.6 \\
71.2 \\
71.2\end{array}$ \\
\hline
\end{tabular}

(d)
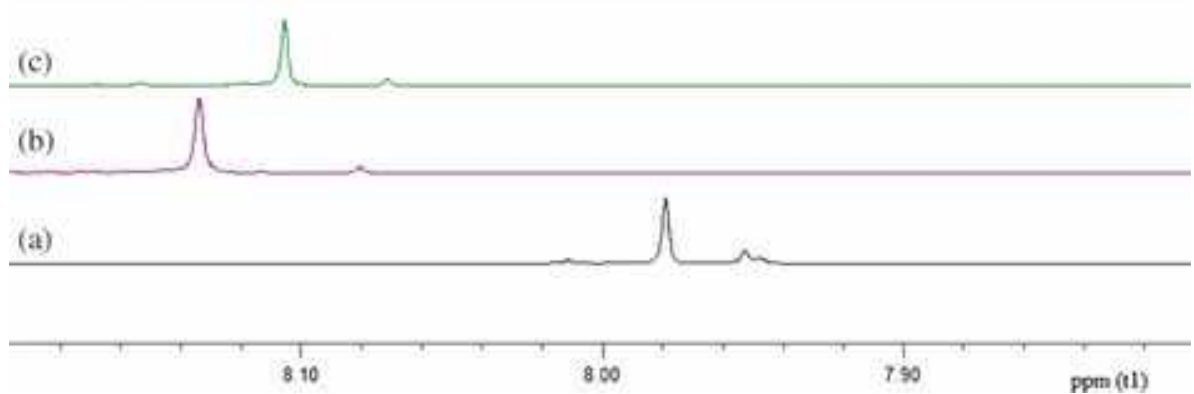

Figure 5. The ${ }^{1} \mathrm{H}-\mathrm{NMR}$ spectra of the 1,2,3-triazole ring proton in $\mathrm{CD}_{3} \mathrm{OD}$ for uncomplexed ligand $\mathbf{L 2}$ (a) and after adding silver ion with the $\mathrm{Ag}^{+}: \mathbf{L} 2$ molar ratio (b) $0.5: 1$, (c) $1: 1$ and (d) $2: 1$. 
There are also proton shifts observed for the $\mathrm{CH}_{2}-\mathrm{N}$ as well as $\mathrm{O}-\mathrm{CH}_{2}-\mathrm{C}=\mathrm{C}$ groups bonded to the 1,2,3triazole rings. The significant proton shift $(0.09$ and $0.14 \mathrm{ppm}$ for $\mathrm{CH}_{2} \mathrm{~N}$ and $\mathrm{O}-\mathrm{CH}_{2}-\mathrm{C}=\mathrm{C}$, respectively) (table 2) in this region seems to confirm the additional participation of oxygen atoms in the formation of the probable sandwich-like complex. Such trends in the coordination (namely, the possible interaction of silver(I) cation with both the nitrogen atom from triazole ring and oxygen atom from the crown ether moiety) was expected on the basis of the preliminary theoretical calculations (DFT method) which indicated the possibility of such kind of cooperation is one of the energetically

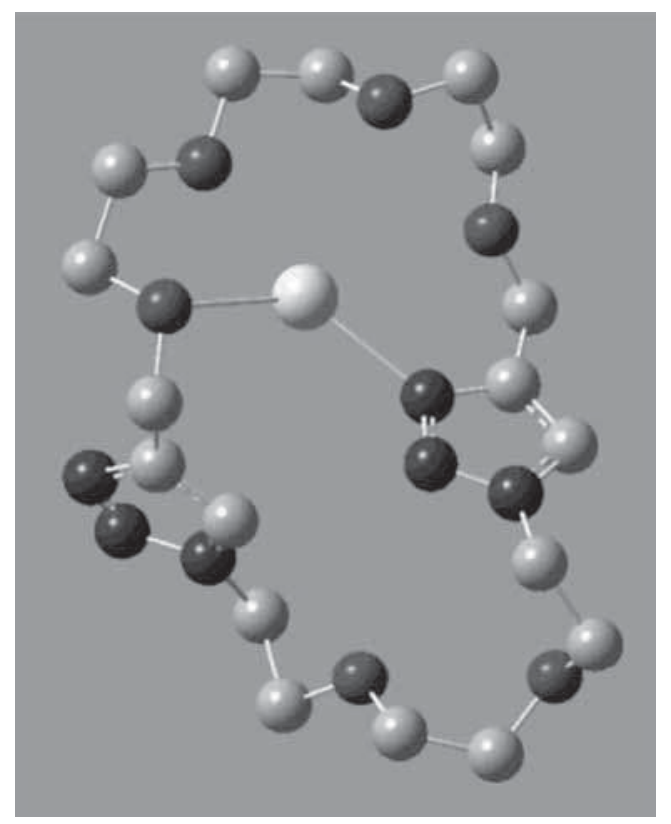

Figure 6. The model structure of calculated complex of $\mathbf{L} 2$ with silver ion. possible ways of binding in 1:1 complex, as shown in figure 6.

The existence of this form of the complex was confirmed by the ESI-MS experiments. The observed at $\mathrm{m} / \mathrm{z} 959.70$ peak (figure 7) can be attributed to the sandwich-like complex. The isotopic pattern of the signals clearly prove the suggested (existing) form of the compound.

The structure formed at the first stage of coordination process is going to reconfigure during further addition of silver ions. The significant upfield chemical shift of the $\mathrm{O}-\mathrm{CH}_{2}-\mathrm{C}=\mathrm{C}$ protons (from 4.77 to $4.65 \mathrm{ppm}$ ) suggests formation of 1:1 complex based mainly on the interactions of nitrogen atoms of triazole rings with the silver ions. Results obtained from the ESIMS experiment (figure 7) show the characteristic (silver isotopes in double form) signal at $\mathrm{m} / \mathrm{z} 533.34$ which confirm the existence of the complex of 1:1 stoichiometry. The observed additional peaks of adducts of the parent molecule with $\mathrm{Na}^{+}$and $\mathrm{K}^{+}$ions $(\mathrm{m} / \mathrm{z} 449.43$ and 465.40 , respectively) as well as the parent compound $\left(\mathrm{m} / \mathrm{z} 427.37-\mathbf{L} \mathbf{2}+\mathrm{H}^{+}\right)$suggest that in the case of $\mathbf{L} \mathbf{2}$ the stability of the complex is much lower in comparison with the one with L1 ligand.

In the last coordination step, dinuclear complex seems to be formed by the binding of the second silver ion with oxygen atoms from the macrocyclic ring located close to the 1,2,3-triazole unit. The lack of shift within the $-\mathrm{O}\left(\mathrm{CH}_{2}\right)_{2} \mathrm{O}$ - regions suggests that the main interactions between ligand and the metal ion are situated within the triazole moieties of the ligand. Such a behavior is considerably different from that observed for the sulfur analogues as well as for similar compounds investigated in previous studies ${ }^{26}$ in which other oxygen atoms were usually involved in the coordination process.

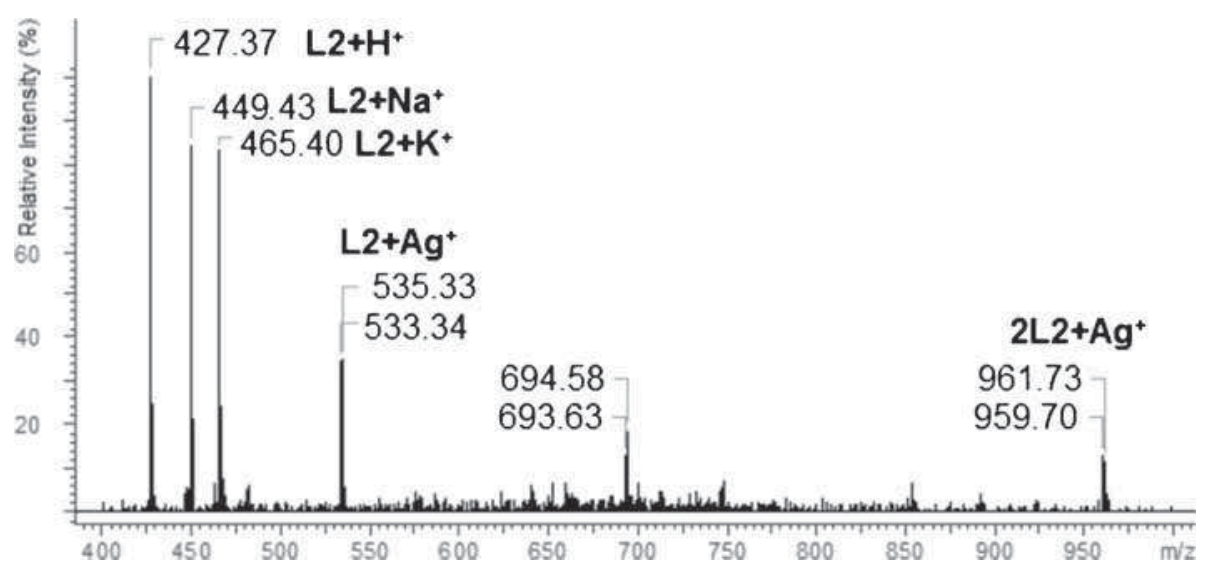

Figure 7. The ESI-MS spectrum of the complexes of $\mathbf{L 2}$ with $\mathrm{Ag}^{+}$ions. 


\section{Conclusions}

The diazides and dialkyne podands derived from dior triethylene glycols were used for the preparation of sulfur and oxygen containing macrocycles with built-in 1,2,3-triazole ring. Complexation study monitored by NMR was carried out for both of the investigated ligands indicating formation of three types of complexes with stoichiometry $\mathrm{AgL}_{2}{ }^{+}, \mathrm{AgL}^{+}$and $\mathrm{Ag}_{2} \mathrm{~L}^{2+}$. Interestingly, in the case of ligand $\mathbf{L} \mathbf{1}$, the sulfur atoms of the macrocyclic system are involved in binding with silver cation in the first two stages of the complexation process. Only when the second silver ion is attached to the ligand, the nitrogen atoms of 1,2,3-triazole rings take part in the complex formation. On the other hand, in case of the ligand $\mathbf{L} \mathbf{2}$ in the first two steps of complexation the nitrogen atoms of endocyclic 1,2,3-triazole rings are the main donors in the coordination process. The second silver ion is bound by oxygen donor atoms connected close to the 1,2,3-triazole moieties in the formation of dinuclear complex with silver ions. Such different modes of coordination in the investigated species suggest that sulfur atoms located in crown ether moiety are more favorable than nitrogen atoms in triazole rings in the binding of silver (I) cation.

\section{Supplementary Information}

All additional information pertaining to characterization of the ligands and their complexes using ${ }^{1} \mathrm{H}$ NMR spectra (figures S1-S8) as well as HMBC and HMQC spectra for the ligand (figures S9-S12) are given in the Supporting Information. Supplementary Information is available at www.ias.ac.in/chemsci.

\section{Acknowledgments}

Authors thank for financial support from National Science Center in Cracow (Grant No. DEC-2011/01/B/ ST5/06613) and to the Academic Computer Center CYFRONET-KRAKÓW for providing computer time and facilities (research project MNiSW/SGI3700/ UŁódzki/043/2010)

\section{References}

1. Tornoe C W, Christensen C and Meldal M 2002 J. Org. Chem. 673057
2. Rostovtsev V V, Green L G, Fokin V V and Sharpless K B 2002 Angew. Chem. Int. Ed. 412596

3. Lutz J-F 2007 Angew. Chem. Int. Ed. 461018

4. Binder W H and Sachsenhofer R 2007 Macromol. Rapid Commun. 2815

5. Meldal M and Tornoe C W 2008 Chem. Rev. 1082952

6. Pasini D 2013 Molecules 189512

7. Megiatto J D and Schuster D I 2008 J. Am. Chem. Soc. 13012872

8. Caricato M, Olmo A, Gargiulli C, Gattuso G and Pasini D 2012 Tetrahedron 687861

9. Pacini A, Caricato M, Ferrari S, Capsoni D, Martínez de Ilarduya A, Muñoz-Guerra M and Pasini D $2012 \mathrm{~J}$. Polym. Sci. A. Polym Chem. 504790

10. Wessjohann L A, Rivera D G and Vercillo O C 2009 Chem. Rev. 109796

11. Zhang W and Moore J S 2006 Angew. Chem. Int. Ed. 45 4416

12. Gibson S E and Lecci C 2006 Angew. Chem. Int. Ed. 45 1364

13. Gokel G W, Leevy W M and Weber M E 2004 Chem. Rev. 1042723

14. Szczukocki D, Dałkowski R, Krawczyk B, Zieliński M, Juszczak R, Kubisiak-Banaszkiewicz L, Olejniczak B and Andrijewski G 2015 Arch. Environ. Prot. 41 15

15. Tomczyk D, Andrijewski G, Nowak L, Urbaniak P and Sroczyński D 2012 Inorg. Chim. Acta 390 70

16. Tomczyk D, Nowak L, Bukowski W, Bester K, Urbaniak P, Andrijewski G and Olejniczak B 2014 Electrochim. Acta $\mathbf{1 2 1} 64$

17. Brandt K, Seliger P, Grzejdziak A, Bartczak T J, Kruszyński R, Lach D and Silberring J 2001 Inorg. Chem. 403704

18. Seliger P, Andrijewski G, Siwy M and Sèk D 2009 Pol. J. Chem. 83581

19. Seliger P, Sołtys N, Andrijewski G and Siwy M 2012 New J. Chem. 362607

20. Romański J and Stefaniak M 2013 Phosphorus, Sulfur Silicon Rel. Elem. 188496

21. TURBOMOLEV6.0 2009, TURBOMOLE GmbH, http://www.turbomole.com

22. (a) Becke A D 1988 Phys. Rev. A 38 3098; (b) Perdew J P 1986 Phys. Rev. B 338822

23. Eichkorn K, Treutler O, Öhm H, Häser M and Ahlrichs R 1995 Chem. Phys. Lett. 242652

24. Stefaniak M, Jasiński M and Romański J 2013 Synthesis 452245

25. Binauld S, Hawker C J, Fleury E and Drockenmuller E 2009 Angew. Chem. Int. Ed. 48 6654; 2009 Angew. Chem. 1216782

26. Sołtys N, Seliger P, Andrijewski G and Siwy M 2013 RSC Adv. 325351

27. Gutowska N, Pasternak B, Seliger P and Andrijewski G 2015 New. J. Chem. 391761 